\title{
Study on Relationship between Recruitment and Selection and Employee Performance in Technical Training Institutes in Kenya
}

\author{
${ }^{1}$ Rose Syombua Matolo*, ${ }^{2}$ Prof. Mike Iravo, ${ }^{3}$ Prof. Gichuhi A. Waititu \\ Jomo Kenyatta University of Agriculture and Technology \\ College of Human Resource \& Development \\ P.O. Box 62000-00200 \\ Nairobi, Kenya
}

\begin{abstract}
The purpose of the study was to establish the relationship between Recruitment and Selection and the employee performance in Technical Institutes in Kenya. Human resource is an important corporate asset and the overall performance of company depends on the way it is put to use. In order to realize company objectives, it is essential to recruit people with requisite skills, qualification and experience and while doing so Human Resource Managers need to keep present and future requirements of organization in mind. The technical training institutes have in the recent past, faced transformation, expansion, conversions/upgrading and competition from other service delivery organizations. The objective was be to find out the relationship between recruitment and selection, and employee performance in technical training institutes in Kenya. The research adopted both descriptive and correlational research designs and a mixture of an approach consisting of both qualitative and quantitative research methods. A sample size of three Technical Institutes in Kenya and comprising of 137 respondents was used. A linear regression analysis was used to explain the relationship between independent variables and dependent variable. The data was analyzed and presented using the statistical methods amongst them tables, bar graphs and pie charts. The results were used test and determine the relationship of the variables. The findings revealed that employee welfare and reward management had the greatest effect on performance. The findings of the research was that there was a significant positive relationship between recruitment and selection and employee performance.
\end{abstract}

Keywords: Human Resource Management, Recruitment and Selection, Performance, Employee Performance, Motivation, Technical Institutes in Kenya.

\section{Introduction}

Recruitment means search of the prospective employee to suit the job requirements as represented by job specification-a technique of job analysis. It is the first stage in selection which makes the vacancies known to a large number of people and the opportunities that the organization offers. In response to this knowledge, potential applicants writes to the organization and this process of attracting people to apply is called recruitment (Watson,1994). Recruitment is defined as, "a process to discover the sources of manpower to meet the requirements of the staffing schedule and to employ effective measures for attracting that manpower in adequate numbers to facilitate effective selection of an efficient workforce(Anderson, 2001). Recruitment is almost central to any management process and failure in recruitment can create difficulties for any company including an adverse effect on its profitability and inappropriate levels of staffing or skills, in addition, inadequate recruitment can lead to labor shortages, or problems in management decision making. Successful recruitment methods include a thorough analysis of the job and the labor market conditions.

Recruitment and Selection is one of the key HRM practice and assists in formal policies, and philosophies that are designed to attract, develop, motivate and retain employees who ensure the effective functioning of 
the organization (Tan \& Nasurdin, 2010). Employees are very important assets of an organization as they contribute to its growth and success (Danish and Usman, 2010). Malik et al. (2010) concluded that in the era characterized by rapid and continuous change, knowledge capital must be retained in order for organizations to be productive and responsive to the needs of their stakeholders. Likewise, institutions including technical training institutes need to attract, retain and develop their employees. Organizations and this includes technical training institutes need employees who are well trained and motivated so that they are committed to their work of conducting research and training for the development of the nations (Lew, 2009). Research literature has shown that effective application of some human resources management (HRM) practices enable employees to be committed to their work for good performance (Chen et al., 2009; Shahzad et al., 2008). According to Harter, Schmidt, and Hayes (2002), HRM practices can generate increased knowledge, motivation, synergy, and commitment of any firm's employees, resulting in a source of sustained competitive advantage for the firm.

Recruitment is however not just a simple selection process but also requires management decision making and extensive planning to employ the most suitable manpower. Competition among business organizations for recruiting the best potential candidate has increased focus on innovation, and management decision making and the selectors aim to recruit only the best candidates who suit the corporate culture, ethics and climate specific to the potential organization. The process of recruitment does not however end with application and selection of the right people but involves maintaining and retaining the employees chosen.

The degree of presence or absence of HRM practices in any technical training institute will most likely have an effect on the management (Gibson, 2010). It is also argued that organizations develop HRM practices that genuinely reflect their beliefs and principles, goals and objectives and the relationship between management and employees, or they may merely devise practices that deal with current problems or requirements (Dessler, 2002). These practices include recruitment and selection, training and development, performance management, remuneration systems, occupational health and safety, industrial relations, human resource information system, human resource planning etc (Oakland \& Oakland 2001; Armstrong, 2006). Several theoreticians have argued that the human resources of an organization are potentially the only source of sustainable competitive edge for organizations (Mutula, 2008). Armstrong (2006) advocates that an organization's economic growth depends on its productivity. If an organization's productivity increases day by day, it will run smoothly and attain the highest possible level of productivity to ensure sustainability of the organization.

Technical training institutes have a lot to sell, which makes them uniquely dependent on their employees' and volunteers' attitudes and motivations and on good HRM practices (Gibson, 2010). Where there is functional, HRM practices, employees will tend to feel that their performance contributions, capabilities and efforts are being recognised (Ng'ethe, 2012). Nyamberega (2005) and Okumbe (2001) also observe that organizations with good HRM practices are able to not only retain its talented employees, but also able to attract the best employees from the labour market.

HRM is all about organizations dealing and handling people as their most important assets of and technical training institutes are not exceptional. Kenya had thirty one (32) technical training institutes before the government devolved its counties. They have in the recent past experienced challenges like transformation and upgrading to institutes of higher learning, and cut-throat competition, advancement in information technology, and leadership wrangles and therefore they are determined to have a sustainable competitive advantage by being trying to remain meaningful, relevant, effective, and fruitful (Kamau, 2008). Vast majority of empirical research is focused on the organizational performance issue, and most studies show that well directed human resource management practices and leadership do increase firm's performance. The objective of the research was to find out the relationship between recruitment and selection and employee performance in technical training institutes in Kenya.

\section{Literature Review \\ Theoretical Frameworks \\ Participative Decision Making Theory}

Likert originally explored the idea of how organizational leaders make decisions. In his writings (The Human Organization, 1967) ideas were based in the notion that supervisors with strong worker productivity 
tended to focus on the human aspects of subordinate problems while creating teams that emphasized high achievement. In other words, these supervisors were employee centered and believed that effective management required treating employees as humans and not just worker bees. Likert further noted that these highly productive leaders also tended to involve subordinates in the decision making process. Out of this basic understanding of productive versus unproductive management, Likert created a series of four distinct management styles/systems. This can apply when recruiting and selecting where by the training institutes include staff in the process. This creates trust and transparency

Exploitive Authoritative: System 1, exploitative authoritative management, starts with the basic issue of trust. Under this system of management, the manager simply does not trust subordinates and has no confidence in subordinate decision making capabilities. Because of this lack of trust, all decisions are simply decided upon by people at the upper echelons of the hierarchy and then imposed on the workers. Communication under these leaders is typically unidirectional (from management to workers), and employees are motivated to comply with management dictates out of fear.

Benevolent Authoritative: System 2, benevolent authoritative management, starts with the basic notion that decision making should be situated with those in managerial positions. Because managers believe that decision making should be theirs and theirs alone, managers believe that workers will simply comply with managerial dictates because of the manager's legitimate right to make decisions. This type of management almost takes on a master-servant style relationship. As for communication, subordinates are not free to discuss decisions or any job-related matters with their superiors. This can affect the perfornance of the employee.

Consultative: System 3, consultative management, starts with a lot more trust in employee decision making capabilities. However, the manager may either not have complete confidence in employee decision making or may have the ultimate responsibility for decisions made, so he or she does not allow workers to just make and implement decisions autonomously. Typically, the manager seeks input from workers and then uses this input to make the ultimate decision. Under consultative management, communication, decision making participation, and teamwork is fair, and employees tend to be more motivated and satisfied than the previous two styles of management. However, consultative management can be very effective if, and only if, the input process is conducted legitimately. One of the biggest mistakes some managers make is to use pseudoconsultative practices where they pretend to seek out input from subordinates even though the actual decision has already been made. Pseudo-consultative decision making is just a different flavor of benevolent authoritative management.

Participative: System 4, participative management, is built on the goal of ensuring that decision making and organizational goal attainment is widespread throughout the organizational hierarchy. In these organizations, organizational leaders have complete confidence in worker ability to make and implement decisions, so workers are constantly encouraged to be very active in the decision making process. Under participative management, communication, decision making participation, and teamwork is good, and employees tend to be motivated and satisfied.

Likert believed that an organization's performance is based on the systems or structures in place for the workers. Thus, Likert believed that organizations could incorporate some aspects from the scientific management approach, human relations, and human resource approach in order to maximize organizational outcomes. 
Two Way Street Theory: Recruitment is a two way street and it takes the recruiter-organization and the recruitee-employee on equal footing. Both need each other and essentially no party is doing the other a favor hence the organization has a choice on who to recruit and-or the prospective employee has to decide which organizational job to apply.

Objective Factor Theory: Assumes that applicants use a very rational method for making decisions, thus the more information prospective organization can give to them for example (salaries, benefits, working conditions etc) the better applicants weigh these factors to arrive at a relative desirable results index.

\section{Critical Content Theory}

Assumes that key attraction is quality of content with the recruiter or recruiter behaviour for example promptness, warmth, follow up calls, sincerity among others. Research indicates that more recruiter contact enhances acceptance of offer, also experienced recruit for instance (middle aged) more successful than young or inexperienced recruiter may be especially when recruiting the minorities, women among others.

\section{Subjective Theory}

Assumes that applicants are not rational but respond to social or psychological needs such as (security, achievement, affiliations etc). Thus they play to these needs by highlighting job security or opportunities for promotion or collegiality of work groups among others

\section{Conceptual Framework}

A conceptual framework refers to an organized way of thinking about how and why a project takes place and how we understand its activities. Kothari (2008) explains that a framework can help us to explain why we are doing a project in a particular way. It can also help us to understand and use the ideas of others who have conducted similar studies. Mugenda (2006) argues that a conceptual framework can also be used like a travel map. The scale on a map tells us how far apart different places are. It is therefore, possible to get an idea on how long it might take to move from one point to the next. According to Kothari (2008), a concept which can take on different qualities of qualitative values is called a variable. If one variable depends on or is a consequence of another variable, it is dependent variable. The variable that is antecedent to the dependent or that makes it to change is called independent variable. A conceptual framework consists of independent variables which cause changes in the dependent variable. Independent variables are factors that cause, change, affect or influence the outcomes while dependent variables are factors that depend on the independent variables. They are also called outcome, effect variables and criterion. The independent variables in this are Recruitment and Selection and the dependent is performance. According to Aneshensel (2002), the specification of an intervening variable means that the connection between the independent and dependent variables is thought to be indirect, transmitted by means of an intermediary. In this situation, the focal (crucial) relationship exists because the independent variable influences the intervening variable, which, in turn, influences the dependent variable. The effect of the independent variable is transmitted through the intervening variables.. The mediating variables help in avoiding errors in logic that might justify questions about the validity of the final conclusions. In this study the mediating variable is motivation and the dependent variable in this study is employee job performance as illustrated in figure 2.1 below. The research sought to establish the effect of the independent variables on the dependent variable in technical training institutes in Kenya.

\section{Recruitment and Selection}

- $\quad$ Recruitment and Selection Methods

- Matching Job descriptions and specifications

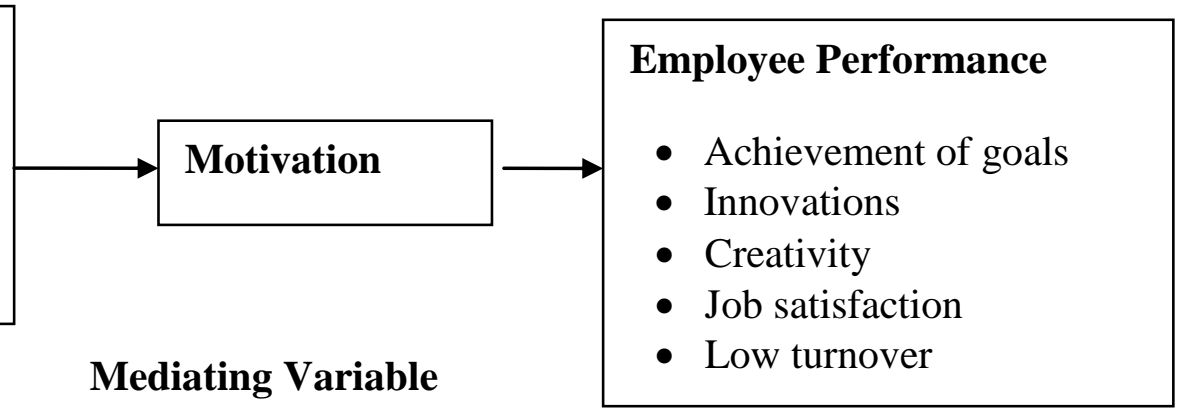




\section{Recruitment And Selection And Employee Performance}

Every organization has its own style and way of recruiting and selecting candidates and it is important that consideration is given at the selection process since under the normal circumstances, an increase in the pool of applicants will improve an employer's opportunities in selecting exactly the right people for job vacancies. Studies done by Bratton \& Gold (2005) and Myloni et al., (2004) have observed Recruitment and selection primarily aims at attracting maximum number of highly talented applicants suitable for the job taking into consideration management goals and legal requirements and selecting the best to in order to achieve competitiveness in the firm. The theory of recruitment is a scholarly body of work about how people can most effectively be persuaded to apply for a job. Recruitment and selection is one of the major functions of HRM and it helps managers attract and select best candidates which in turn leads to improved organization performance (Rehman, 2012). Armstrong (2009) categorizes recruitment and selection into three stages: defining requirement, attracting candidates and selecting candidates. He further argues that Human Resource Managers need to keep present and future requirements of organization in mind. Successful recruitment methods include a thorough analysis of the job and the labor market conditions. It is very important that in any organization, there is a recruitment plan. The recruitment plan according to Armstrong (2009) will cover: the number and type of employees required to cater for expansion or new developments and make up for any deficits, the likely sources of candidates, plans for tapping alternative sources and how recruitment programme will be conducted.

Recruitment includes sourcing candidates by advertising or other methods, screening potential candidates using tests and interviews, selecting candidates based on the results of the tests or interviews, and onboarding to ensure that the candidate are able to fulfil their new roles effectively. Armstrong (2009) has also observed that candidates can be also selected using different methods like individual interviews, interviewing panels, selection boards, and assessment centres in order to assess their suitability for a certain role. The exercise of recruitment activities need to be responsive to the increasingly competitive market to secure suitably qualified and capable recruits at all levels for goals actualization and performance competence. However, to be effective, these initiatives need to include how and when to source the best recruits (McLean et al., 2004). Effective recruitment demands well-defined organizational structures with sound job design, robust task and person specification and versatile selection processes, and employee engagement and on-boarding strategies .Beardwell \& Claydon (2007) observed that the process of recruitment and selection is concerned with identifying, attracting and choosing suitable people and employing and obtaining appropriate and competent candidates through external sourcing and that it gives greater importance to be attached to fit between person and organization's culture. Hence, the high level of implementation of recruitment that attaches individual - organizational fit is likely to result in high job performance and innovation. As also observed by Gupta (2014) that selection can be conceptualized in either choosing the "fit" candidates or rejecting the candidates, or a combination of both. Selection process assumes rightly that there are more candidates than the number of job openings available. The basic idea in selection process is to solicit maximum possible information about the candidates to ascertain their suitability for employment and given the fact that there are factors which affect the seeking of such information Beardwell \& Claydon (2007). They also contended that maximum resource should be dedicated to develop top- quality selection system through both external and internal sources whereby the reason for external context being lack of the specialist skills required, lack of experience required within the organisation, the internal applicants want more than can be offered and lack of internal applicants.

Formal recruitment methods include newspaper classified advertisements, network bulletins, posters and human resource banks, while informal methods include personal connections and introductions through teachers and other staffs (Chen and Cheng, 2012). The effectiveness of different recruitment sources for new employees has been the topic of speculation and research for over 50 years and this effectiveness has primarily been assessed by examining job survival rates and job performance (Breaugh, 2008 and Rehman, 2012). In addition, Ferris et al. (2002) found that effectiveness of recruitment practices has an impact on organizational effectiveness. Similarly, many researchers agreed that effective recruitment and selection will lead to competitive advantage and high performance of organization (Storey, 2007 and Zheng et al., 2006). 
Many organizations prefer to invite applications from internal candidates before they look to their external labour markets and new staff. The authors also found out from their research on methods of recruitment that the highest attraction was through advertisement in the local press at $79 \%$ followed by the following: Recruitment agencies at $76 \%$, Corporate website at $75 \%$, Specialist journals and trade press at $66 \%$, Job centres at $51 \%$, word of mouth at $49 \%$, Employee referral scheme at $47 \%$, Commercial job-boards at $16 \%$ and radio/tv at $7 \%$. This is according to Torrington, Hall \& Taylor (2008). The key stages of recruitment and selection were summarized by Beardwell \& Claydon (2007) as defining the vacancy, attracting applicants, assessing candidates and making the final decisions. Which can also be expressed by asking a series of questions like who do we want? how can we attract them?, how can we identify them?, how do we know we have gotten it right and finally who will be involved in the process?

The link between recruitment and selection process and job performance has been empirically investigated by researchers across the globe. Jonathan et. al. (2012) investigated the effect of recruitment and selection process on the performance of employee in small and medium enterprises in Kisumu municipality, Kenya. This study established that there is a relationship between recruitment and selection process on employees' performance. The study found out that the overall average performance of SMEs in Kisumu Municipality is $60.71 \%$; and that sourcing, attracting, and screening are significant determinants of the performance of the SMEs in Kisumu Municipality. Based on these findings, the study concludes that recruitment and selection have a significant effect on the performance of SMEs in Kisumu Municipality, and the better the recruitment and selection, the higher the performance of the SME. In fact, the performance of SMEs can be influenced by up to $72.40 \%$ through proper recruitment and selection. This implies that the researchers found out that there is a positive relationship between the two variables (recruitment and selection and job performance) According to Ombui et. al. (2014) recruitment and selection process influences performance of employees in research institutes in Kenya. The results of the research show that although there is evidence of recruitment and selection taking place in all research institutes in Kenya, the employees seem not to be involved in making decisions regarding this aspect. The model summary for recruitment and selection appeared to be insignificant, but was nonetheless retained since it was found to have a positive influence on the performance of employees in research institutes in Kenya. It was found out by the researchers that recruitment and selection have a positive effect on employees' job performance in research institute in Kenya after a valid tool were used to test the hypotheses.

The study of Joy and Ugochukwu (2015) on the impact of recruitment and selection process on employees and organisational performance in Nigeria shows that there is positive relationship between recruitment and selection process and performance of employees in organisations. The researchers concluded that Recruitment and selection in any organization is a serious business as the success of any organization or efficiency in service delivery depends on the quality of its workforce who was recruited into the organization through recruitment and selection exercises (Ezeali and Esiagu, 2010). Ibrahim Amadu (2014) critically and empirically examined the link between recruitment and selection process and organizational performance in manufacturing companies in which the researcher also affirmed a positive relationship between recruitment and selection exercise and performance. Samuel et. al., (2015) carried out a study on the roles of recruitment and selection process on employees' performance in cooperative society sector in Africa. From his findings, the study concludes that there is a significant positive relationship between recruitment sources and employee performance in the cooperative sector in Africa. The study further concludes that recruitment and selection policies affect employee performance in the cooperative sector in Africa as it guides recruitment practices and procedures. Finally, recruitment message affects employee performance in the cooperative movement sector in Africa to a very great extent because recruitment message, or job advertisement, will attract applicants who are more qualified for the respective jobs to apply for the vacancies and once selected, they will be motivated and perform better since they understand their job descriptions. The study also concluded that realistic job previews as a form of recruitment message affect employee performance to a very great extent because it influences role clarity which affects job performance and individuals' perceptions that the organization was honest with them (Breaugh and Starke, 2000). Based on the results of the majority of the past researchers on the impact of recruitment and selection 
process, one can concur with Jolaosho, S.O. et al (2018) that recruitment and selection have relationship with performance of employees in organization.

\section{Motivation}

Motivation is a concern of factors that influence people in certain ways, (Grobler et al, 2002). It is a process that accounts for an individual's willingness to apply high levels of effort so as to attain the firm's goals and at the same time satisfy individual needs, (Robins \& Coulter, 2005).

According to Latham and Pinder, (2005), motivation is a process that determines how energy is used to satisfy needs. When an individual has an unsatisfied need, it creates tension which and as a result reduces exerting effort. It is a resource allocation process where time and energy are allocated to a number of tasks. Additionally, motivation is also said to be a desire that causes a person to act, to have initiative, spirit or become enterprising. There are two types of motivation namely, Intrinsic motivation and Extrinsic motivation. Intrinsic is self generated and influences people to behave and move in a certain way, while extrinsic motivation is what is done for or to people to motivate them, (Robinson, 2004). An illustration of motivation is a person's level of self-efficacy which is an individuals belief in self ability to succeed in specific situations or accomplish a task.

There are three elements of motivation: Direction, which refers to what a person is trying to do; Effort which refers to how hard a person is trying and in this regard effort can be said also that it is the element that measures the intensity or drive in an individual. The third motivational element is; Persistence. This is how long a person keeps on trying, (Aronolff \& Ward, 2004). Fair organizational commitment increases the level of employee motivation and gears them to work effectively to achieve the organization goals and objectives, (Taing et al.,2011).

According to Gerhrt and Mikovich (1992), overall those organizations which give the most reward tend to attract and retain most people. There is less absenteeism and employee engagement. The needs satisfaction theories of motivation are example of a normative approach which provides a possible basis for developing the link between HRM and performance. According to (Gerhart and Mikovich, 1992, Lawler 1990 Vroom, 1964), when certain specific conditions exist, reward systems have been demonstrated to motivate performance. This occurs because people have their own needs and mental maps of what the world is like.

Performance motivation depends on the situation, how it is perceived and the needs of the people. This motivation of performance objective is explained by the 'expectancy theory' of Vroom (1964), The Research Centre for Organization Studies of Belgium, (2006), state that basic need satisfaction positively influences effective organizational commitment and work engagement and subsequently lowers turnover intentions. The self determination theory (Deci and Ryan, 2004) argues that individuals have three basic needs, i.e. the need for autonomy, relatedness and competence of which satisfaction is essential for optimal functioning in sev

eral life domains including work (Deci and Ryan 2000). According to CEO (2010), reward systems are often a significant cost factor. Brown (2001) emphasizes the 'alignment of reward practices with employee values and needs'. Brown (2001) suggested that for effective reward practices, they have to have clearly defined goals and well linked to business objectives, they well designed pay and reward programmes, tailored to the needs of the organization and its people, and consistent and integrated with one another

\section{Research Methodology}

The study adopted both descriptive and correlational research designs. The descriptive design was used to obtain and describe information on the critical analysis of the issue of HRM practices on employee job performance of the technical training institutes in Kenya. This is supported by Mugenda and Mugenda (2008) who indicates that the design is suitable and conducted in communities when a researcher wishes to establish the extent of a range of issues such as education, health, nutrition, etc. When one wants to get information on the current status of a person descriptive research design is the most appropriate (Kothari, 2008). Thus the study focused on getting information on the current status of one of the human resource practice i.e. recruitment and selection in the technical training institutes in Kenya and their effect on the employee job performance. It was also a correlational research because it is concerned with assessing the 
relationship among the variables of the study: recruitment and selection and employee job performance. Graeme and Moutinho (2008) justified the use of correlation research in determining whether a relationship exists between or among variables.

\section{Target Population}

Population is composed of those people, events or records that contain the desired information and can answer the measurement questions. The population may consist of individuals, households, or families, or a combination of these as observed by Cooper and Schindler (2011). According to Mugenda and Mugenda (2003), the target population is that population which the researcher wants to generalize results. The target population for this study was employees of the technical training institutes in Kenya. The study concentrated a total of three technical training institutes in Kenya, two in the capital city of Nairobi and one special need students in the outcast of Nairobi CBD. The technical training institutes have different cadres of employees in the institutes. Information was drawn from the Teaching and non-teaching staff from each technical training institute within the Nairobi CBD.

\section{Research Findings And Discussion \\ Response Rate}

This refers to the number of respondents who filled in the research questionnaires successfully against the total number of respondents. According to Nulty (2008), the response rate is deemed sufficient when it reaches $70 \%$. In the study at hand, 167 questionnaires were issued and 137 were filled successfully and 1 questionnaire was filled unsuccessfully. This represents $82 \%$ response rate which according to the researcher was sufficient and above $75 \%$ (Table 1 ).

\section{Table 1: Response Rate}

\begin{tabular}{|l|r|r|}
\hline Responses & No & Percentage \\
\hline Administered Questionnaires & 167 & $100 \%$ \\
\hline Unfilled /not returned & 29 & $17 \%$ \\
\hline Not useful & 1 & $1 \%$ \\
\hline Filled & 137 & $82 \%$ \\
\hline
\end{tabular}

The respondents were expected to give their honest opinion and views by way of some degree of disagreement and agreement on some attributes of Human Resource Recruitment and Selection in the Technical Training Institutes in Kenya. Attributes were measured on a five point Likert-Type scale ranging from 1 as "Strongly disagree" to 5 as "Strongly agree". From the study means that ranged between 2.66-3.98 and standard deviation of range between $1.031-1.410$ were recorded. From the results and as indicated below in Table 4.7 below majority $38.7 \%$ strongly agreed that proper recruitment enhanced a positive influence on the performance of the employees in the Technical Training Institutes.

\section{Findings}

This is as illustrated in the mean below of 3.98 and a standard deviation of 1.046. Great extent of respondents agreed that each member had a clearly spelled out job description. This is at a mean of 3.66 and standard deviation of 1.031. A number of respondents $(27.7 \%)$ neither agreed nor disagreed on whether vacant positions are advertised and filled competitively. This resulted, as evidenced in the table below, a recorded mean of 3.09 and standard deviation of 1.175 . 
Table 2: Findings on Recruitment and Selection

\begin{tabular}{|l|c|c|}
\hline & Mean & $\begin{array}{c}\text { Std. } \\
\text { Deviation }\end{array}$ \\
\hline $\begin{array}{l}\text { Recruitment and selection methods in place are known to all members } \\
\text { of staff }\end{array}$ & 2.66 & 1.410 \\
\hline Vacant positions are advertised and filled competitively & 3.09 & 1.175 \\
\hline $\begin{array}{l}\text { Each member of staff has a job description which is clearly spelled } \\
\text { out }\end{array}$ & 3.66 & 1.031 \\
\hline Recruitment and selection is inclusive of all stakeholders & 2.83 & 1.115 \\
\hline $\begin{array}{l}\text { Recruitment and selection is guided by job analysis, planning and the } \\
\text { existing establishment }\end{array}$ & 2.96 & 1.067 \\
\hline $\begin{array}{l}\text { Heads of departments/sections are involved during shortlisting which } \\
\text { enhances Technical Training Institute objectives }\end{array}$ & 3.42 & 1.103 \\
\hline $\begin{array}{l}\text { Proper Recruitment and Selection has had positive influence on the } \\
\text { performance of Technical Training Institute employees }\end{array}$ & 3.98 & 1.046 \\
\hline Proper recruitment and Selection has enhanced low turnover for staff & 3.45 & 1.057 \\
\hline
\end{tabular}

The study revealed that majority of the respondents agreed that proper recruitment and selection enhanced low turnover for staff members with a mean recorded of 3.45 with a standard deviation of 1.057. Majority did not agree on the of inclusion of stakeholders in the recruitment and selection exercise as evidenced in the mean of mean 2.83 and standard deviation of 1.115. A majority disagreed that recruitment and selection was guided by job analysis, planning and the existing establishment. This recorded a mean of 2.96 and standard deviation of 1.067. This is illustrated in Table 2 above.

\section{Regression Analysis}

From the above analysis in Table 3 below, it is evident that results of the regression analysis indicated that the relationship between recruitment and selection and performance of TTI was a weak positive but statistically significant $(r=0.436 ; p>0.01)$. The results can be backed by the Storey (2007) and Zheng et al, (2006) who support the results and argue that effective recruitment and selection will lead to competitive advantage and high performance. Similarly, Rehman, (2012) found out that Recruitment and selection help managers attract and select best candidates which in turn leads to improved organization performance.

Table 3: Regression Analysis For Recruitment And Selection On Performance

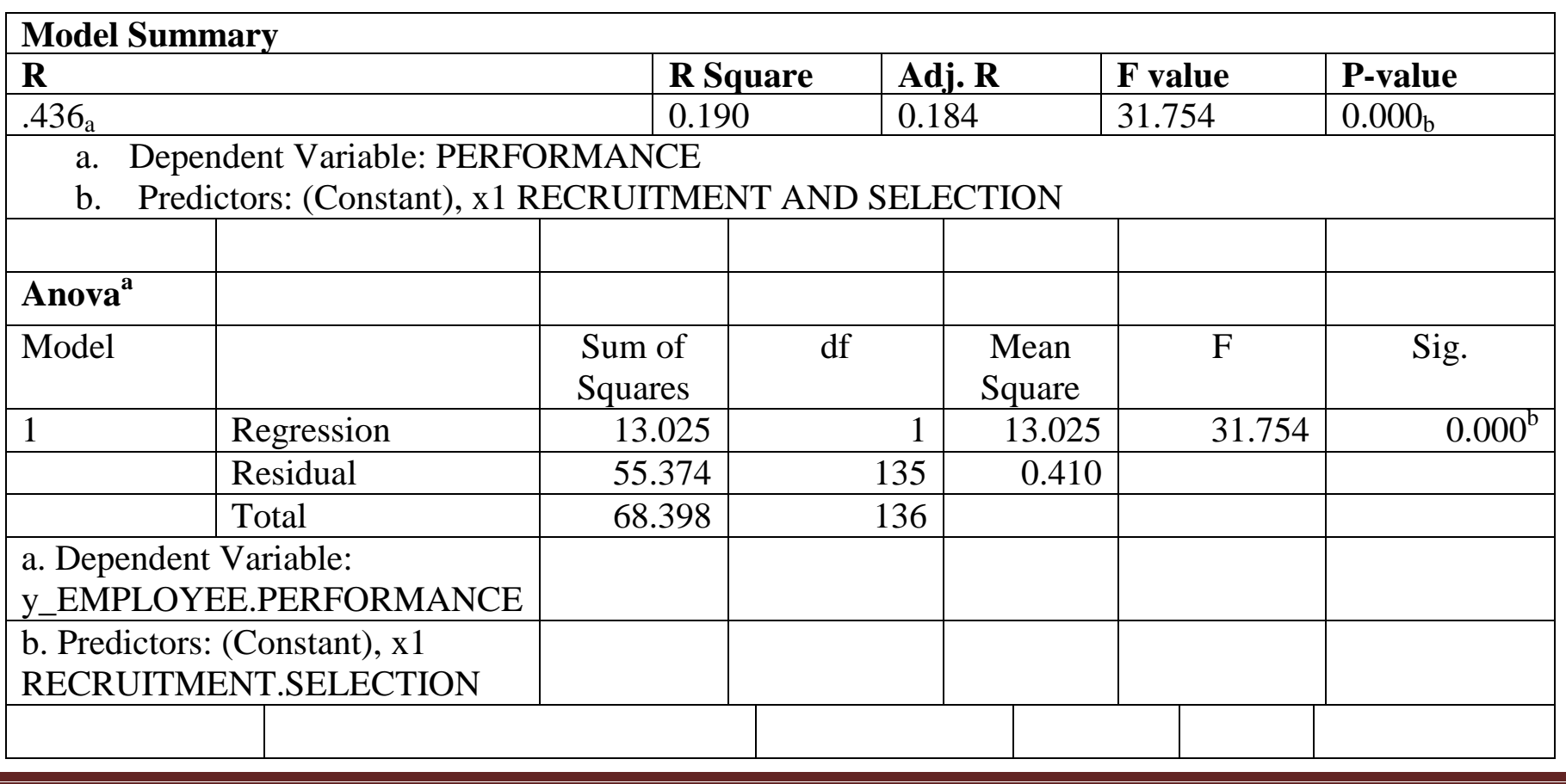




\begin{tabular}{|c|c|c|c|c|c|}
\hline \multicolumn{6}{|l|}{ Coefficients $^{\mathrm{a}}$} \\
\hline Model & & $\begin{array}{l}\text { Unstandardized } \\
\text { Coefficients }\end{array}$ & & $\mathrm{t}$ & Sig. \\
\hline & & $\mathrm{B}$ & $\begin{array}{l}\text { Std. } \\
\text { Error }\end{array}$ & & \\
\hline 1 & (Constant) & 1.710 & 0.262 & 6.527 & 0.0000 \\
\hline & $\begin{array}{l}\mathrm{x} 1 \\
\text { RECRUITMENT.SELECTION }\end{array}$ & 0.443 & 0.079 & 5.635 & 0.0000 \\
\hline $\begin{array}{l}\text { a. Dependent } \\
\text { y_EMPLOYE }\end{array}$ & $\begin{array}{l}\text { riable: } \\
\text { PERFORMANCE }\end{array}$ & & & & \\
\hline
\end{tabular}

Other research findings that concur with the above findings were from Jolaosho, S.O. et al (2018), Breaugh and Starke, (2000), Jonathan et. al. (2012), Ombui et. al. (2014), Joy and Ugochukwu (2015), Ezeali and Esiagu, (2010). Ibrahim Amadu (2014) and Samuel et. al., (2015). They found out that there is a relationship between recruitment and selection process on employees' performance and that there is a positive relationship between the two variables (recruitment and selection and employee job performance). The researchers concluded that Recruitment and selection in any organization is a serious business as the success of any organization or efficiency in service delivery depends on the quality of its workforce who was recruited into the organization through recruitment and selection exercises. They critically and empirically examined the link between recruitment and selection process and performance in and affirmed a positive relationship between them. They found out that recruitment message, or job advertisement, will attract applicants who are more qualified for the respective jobs to apply for the vacancies and once selected, they will be motivated and perform better since they understand their job descriptions thus recruitment and selection have relationship with performance of employees in any organization.

\section{Summary And Conclusion}

The study revealed that each member of staff has a job description which is clearly spelled out. A majority of the respondents indicated that recruitment and selection is inclusive of all stakeholders and that it is guided by job analysis, planning and the existing establishment. The study also revealed that the heads of departments/sections are involved during shortlisting which enhances Technical Training Institute objectives. Proper recruitment and selection has enhanced low turnover for staff. However when it came to transparency, it was revealed that recruitment and selection methods in place were not known to all members of staff.

In conclusion it is evident that results obtained indicated strongly that there is a relationship between recruitment and selection and the performance of the employee.

\section{Recommendation For Further Study}

The study concentrated on the employee performance. There is room for future exploration on the relationship between the other Recruitment and selection and the institute's performance or employee turnover. The institutions covered were the Technical Training Institutes. The study can be broadened to other sectors.

\section{References}

[1] Amadu, I. (2014). The effect of recruitment and selection: Policies and Practices on organizational performance. Kwame Nkrumah University of Science and Technology. Kumasi.

[2] Aneshensel, C. S. (2002). Theory-based data analysis for the social sciences. London: Sage Publications.

[3] Armstrong, M. (2009). Armstrongs's Handbook of Human Resource Management Practice. $\left(10^{\text {th }}\right.$ Ed.). London: Kogan Page. 
[4] Armstrong, M. (2009). Armstrongs's Handbook of Performance Management: An evidence-based guide to delivering high performance. ( $4^{\text {th }}$ Ed.). London: Kogan Page.

[5] Beardwell, J. \& Claydon, T. (2007). Human Resource Management. A contemporary Approach. London: Prentice Hall.

[6] Bratton, J. \& Gold, J. (2005). Human Resource Management: Theory and Practice. (3rd Ed.). Hampshire: Pal grave Macmillan.

[7] Bratton, J.E., \& Gold, J.T, (2003). Human Resource Management Theory and Practice. (6 ${ }^{\text {th }}$ Ed.). New York:Mc Graw-Hill.

[8] Breaugh, J.A. (2008). "Employee recruitment: current knowledge and important areas for future research", Human Resource Management Review, 18(3), 103-118.

[9] Breaugh, J. and Starke, M. (2000). Research on employee recruitment: So many studies, so many remaining questions. Journal of Management, 26.405-434

[10] Brown, C.B. \& Campbell, B. (2001), "Technical change, wages, and employment in semiconductor manufacturing", Industrial and Labor Relations Review, 54, 450-66.

[11] Chen, S.H., Wang, H. \& Yang, K. J. (2009), "Establishment and application of performance measure indicators for universities", The TQM Journal, 21(3), 220-235.

[12] Chen, Y.G. \& Cheng, J.N. (2012). "The relationships among recruitment channels, understanding of perspective job, job performance and turnover intention among Taiwanese kindergarden teachers", Social Behavior \& Personality: An International Journal, 40(1), 93-103.

[13] Cooper, D. \& Schindler, P. (2011). Business Research Methods. (11 ${ }^{\text {th }}$ Ed). McGraw-Hill: International Edition.

[14] Danish, R.Q. \& Usman, A. (2010). "Impact of reward and recognition on job satisfaction and motivation: an empirical study from Pakistan", International Journal of Business and Management, 5(2), 159-167.

[15] Denis, C. \& Michel, T. (2011). "Between universality and contingency: an international study of compensation performance", International Journal of Manpower, 32(8), 856-878.

[16] Dessler, G. (2002). Human Resource Management. New Delhi: Prentice hall.

[17] Ezeali, B.O. and Esiagu, L.N. (2010). Public personnel management. Human Capital Management Strategy in the 21st Century. Onitsha: Book Point Limited.

[18] Gibson, L.L. (2010). Human Resource Management Practices in the Church: A Study of the H.R. Practices in the Church of God Reformation Movement in Barbados. USA: Dorrance Publishing

[19] Graeme, D.H., \& Moutinho, L. (2008). Statistical modelling for Management, London: Sage publications limited.

[20] Gupta, N. \& Shaw, J.D. (2014). Employee Compensation: The neglected area of HRM research. Human Resource Management Review, 24, 1-4

[21] Harris, L. (2005). Reward Strategies and paying for contribution. In: J. Leopold, L. Harris \& T. Watson, Eds, The Strategic Managing of Human Resources. New York: FT Prentice Hall.

[22] Harter, J. K., Schmidt, F. L. and Hayes, T. L. (2002). Business-Unit-Level relationship between employee satisfaction, employee engagement, and business outcomes: A meta-analysis, Journal of Applied Psychology, 87(2), 268-279.

[23] Jonathan, W.O., Moses, N.O., and Willis, Y.O. (2012). Effect of recruitment and selection of employees on the performance of small and medium enterprises in Kisumu Municipality, Volume 4 Issue 02 February 20181650 Kenya. International Journal of Human Resource Studies. 2(3), 139150.

[24] Joy, O.E, Ugochikwu, U.I, and Ndubuisi, U. (2015). The Impact of recruitment and selection criteria on organizational performance. Global Journal of Human Resource Management, 3(2). 22-33.

[25] Jolaosho, S.O. et al (2018). The Effect of Recruitment and Selection Process on Job Performance in Telecommunication Industry in Nigeria: An Assessment of MTN Customer Service Centre Abeokuta. International Journal of Management and Economics. 4(02), 1639-1651.

[26] Kothari, C. \& Garg, G (2014). Research Methodology, Methods and Techniques. ( ${ }^{\text {rd }}$ Ed.). New Delhi: New Age International.

[27] Kothari, C. (2008). Research Methodology, Methods and Techniques. New Delhi: Wiley Easton. 
[28] Latham, G.P \& Pinder, C.C., (2005). Work Motivation Theory and research at the dawn of the twentieth century. Annual Review of Psychology, 56: 485-516.

[29] Lawler, E.E.III., \& Mohrman, S.A., (2003). HR as a Strategic Partner: 26(5), 15-29 NewYork: Mc Graw Hill.

[30] Lew, T.Y. (2009). "Perceived organizational support: linking human resource management practices with affective organizational commitment, professional commitment and turnover intention", The Journal of International Management Studies, 4(2), 104-115.

[31] Likert, R. (1967). The human organization: Its management and value. New York: McGraw-Hill.

[32] Malik, M.E., Nawab, S., Naeem, B. \& Danish, R.Q. (2010), "Job satisfaction and organization commitment of university teachers in public sectors of Pakistan", International Journal of Business and Management, 5(6), 17-26.

[33] Mugenda, G., \& Mugenda, V. (2003). Research Methods. Nairobi: Acts Press.

[34] Mugenda, O., \& Mugenda, A. (2003). Research Methods: Quantitative and Qualitative approaches. Nairobi: Acts Press.

[35] Mutula, S.M. (2008). Comparison of sub-Saharan Africa's e-government status with developed and transitional nations. Journal of Information Management and Computer Security, 16 (3), 235-250.

[36] Ng'ethe, J.M. Iravo, M.E., \& Namusonge, G.S. (2012). Determinants of Academic Staff Retention in Public Universities in Kenya: Empirical Review. International Journal of Humanities and Social Science, 2 (13).

[37] Nulty, D.D. (2008). The adequacy response rates to online and paper surveys. Assessment \& Evaluation in Higher Education, 33(3), 301-314.

[38] Oakland, S., \& Oakland, J.S. (2001). Current people management activities in world- class organizations. Total Quality Management. Sept, 773-79.

[39] Ombui, K., Elegwa, M. and Gichuhi, A.W. (2014). The Influence of recruitment and selection on the performance of employees in research institutes in Kenya. IJSR, 3(5). 132-138.

[40] Rehman, S. (2012). "A study of public sector organizations with respect to recruitment, job satisfaction and retention”, Global Business \& Management Research, 4(1), 76-88.

[41] Richard et al. (2009), Measuring organizational performance towards methodological best practices, journal of management 29.

[42] Ryan, R.M. \& Deci, E. L., (2000). Intrinsic and Extrinsic Motivations: Classic Definitions and New Directions, Contemporary Educational Psychology 25, 54-67

[43] Samuel, M. \& Chipunza, C., (2009). Employee retention and turnover: Using motivational variables as a panacea. African journal of business management, 3(8), 410-415.

[44] Samuel, O. M., George, C.M., and Beth, W.N. (2015). Effects of recruitment practices on employee performance in the cooperative sector in Kenya: Case of Kenya Union of savings and credit cooperatives. IJSR 4(5), 1476-1481.

[45] Shahzad, K., Bashir, S. \& Ramay, M.I. (2008). "Impact of human resource practices on perceived performance of university teachers in Pakistan", International Review of Business Research Papers, 4(2), 302-315.

[46] Storey, J. (2007). Human Resources Management: A Critical Text, 3rd ed., Thomson Corporation, London.

[47] Taing et al (2011). The multidimensional nature of continuance commitment: commitment owing to economic exchanges versus lack of employment alternatives. Journal of Business and Psychology, 26(3).

[48] Tan, C. L., \& Nasurdin, A. M., (2010). Hman Resource Management Practices and Organizational innovation: Assessing the Mediating Role of Knowledge Management Effectiveness. The Electronic Journal of Knowledge Management, 9(2), 155-167.

[49] Torrington, D., Hall, L. \& Taylor, S. (2008). Human Resource Management. ( ${ }^{\text {th }}$ Ed.). London: Prentice Hall.

[50] Zheng, C., Mark, M. \& O’Neill, G. (2006). “An empirical study of high performance HRM practices in Chinese SMEs", International Journal of Human Resource Management, 17(10), 1772-1803. 